\title{
Social support and the incidence of cognitive impairment among older adults in China : Findings from the CLHLS study
}

Shufei Yin

Hubei University

Quan Yang

Hubei University

Jinli Xiong

Hubei Univeristy

Tian Li

Beijing Normal University

Xinyi Zhu ( $\square$ zhuxy@psych.ac.cn )

Institute of Psychology Chinese Academy of Sciences https://orcid.org/0000-0002-7361-8958

Research article

Keywords: social support, older adults, cognitive impairment, CLHLS

Posted Date: December 15th, 2019

DOI: https://doi.org/10.21203/rs.2.18404/v2

License: (9) This work is licensed under a Creative Commons Attribution 4.0 International License.

Read Full License 
The authors have withdrawn the journal submission associated with this preprint and requested that the preprint also be withdrawn. 